International Journal of Engineering \&Technology, $7(3.12)(2018)$ 168-170
International Journal of Engineering \& Technology
SPC
Website: www.sciencepubco.com/index.php/IJET
Research paper

\title{
Utilization of Cow-dung Ash, Granite Powder and Marble Stone to Enhance Strength of Concrete
}

\author{
J Arthika $^{1}$, C Venkatasubramanian ${ }^{2}$, D Muthu ${ }^{3}$, Neha P Asrani ${ }^{4}$, R. Gayathri ${ }^{5}$ \\ $1,4,5$ M.tech Student, ${ }^{2}$ Associate Professor, ${ }^{3}$ Assistant Professor, \\ ${ }^{1,2,3,4,5}$ School of Civil Engineering, SASTRA Deemed University, Thanjavur 613401, India. \\ *Corresponding Author Email: ' arthijagathees@ gmail.com
}

\begin{abstract}
The construction industry has been responsible for degrading the environment due to ecological imbalance caused during the extraction and production of building materials. To make this production of construction materials cleaner, the dependency on conventional materials has to be reduced. With this aim, this article presents an experimental study on partial replacement of cement, sand and aggregate by cowdung ash(CDA), granite powder(GP) and marble stone(MS) respectively. For this, four series of mix proportions were prepared to evaluate the compressive strength and the split tensile strength. Replacement ratios of the first, second, third and fourth mixes are (5\% CDA, $10 \% \mathrm{GP}, 15 \% \mathrm{MS}),(5 \% \mathrm{CDA}, 15 \% \mathrm{GP}, 30 \% \mathrm{MS}),(10 \% \mathrm{CDA}, 15 \% \mathrm{GP}, 30 \% \mathrm{MS}),(5 \% \mathrm{CDA}, 7.5 \% \mathrm{GP}, 15 \% \mathrm{MS})$ respectively. Results revealed that the partial replacement of binders and fillers is effective to enhance compressive and split tensile strength of concrete. This would enable the construction industry to reduce their dependency on river sand and natural coarse aggregate.
\end{abstract}

Keywords: Cement, Cowdung ash, Granite powder, Marble stone, Strength.

\section{Introduction}

Concrete is the world's most consumed man-made material due to its high strength, durability and availability. However, its production is not environment friendly this requires an attempt to identify industrial byproducts as partial replacement to cement and aggregates. Cement can be replaced with industrial by-products such as Fly ash, GGBS, Cowdung ash etc., as they have good binding properties. Fine aggregate can be replaced by Granite powder due to non-availability of river sand. Moreover granite powder is a by-product of granite stone crushing process that has been a waste material throughout the years. Marble stones have no method of systematic disposal of waste in the quarrying areas. Thus it can be used in replacing coarse aggregate.

According to Roshanlal et.al.[1], marble and granite as coarse aggregates give high strength to concrete at early stages with $20 \%$ and $30 \%$ replacement ratios. The compressive strength is increased by $8.7 \%$ and $5.5 \%$ respectively. The tensile strength is increased by $12 \%$ and $6 \%$ respectively.Ojedokun.O.Y et.al.[2], stated that cowdung ash can be used to produce light weight concrete. The usage of cowdung ash can be restricted to less than $10 \%$ and can be used for finishing, flooring and temporary structures.Omoniyi $\mathrm{T}$ et.al.[3], investigated that replacement of cement with cowdung ash should not be more than $15 \%$. Increase in cowdung ash increases the setting time, hence it can be used in hot weather.Dr.T.Felix Kala [5], stated that the use of granite powder in concrete has beneficial effects on the mechanical properties such as compressive, tensile and flexural strength of concrete. Early attainment on strength at 7 days is obtained. Hence it can be used in bridge and dam construction.
Pranali K kohad et.al.[6], reported that increase in marble more than $15 \%$ increases workability but affects compressive strength. The flexural strength is increased when compared to conventional concrete. The replacement of $30 \%$ aggregate by recycled marble stone gives maximum compressive strength of concrete. Manasseh JOEL [8], performed slump, compressive and indirect tensile strength on fresh and hardened concrete by partially replacing river sand with crushed granite powder. Based on economic analysis and results of test river sand replaced with $20 \%$ granite powder is recommended for use.

The advantages of using Cowdung ash, granite powder and marble stone have been studied in our literature review. The scope of this investigation is to study the variations of strength characteristics in concrete by replacing materials. The replacement ratios of the first, second, third and fourth mixes are (5\%CDA, $10 \% \mathrm{GP}$, $15 \% \mathrm{MS}),(5 \% \mathrm{CDA}, 15 \% \mathrm{GP}, 30 \% \mathrm{MS}),(10 \% \mathrm{CDA}, 15 \% \mathrm{GP}$, $30 \% \mathrm{MS}),(5 \% \mathrm{CDA}, 7.5 \% \mathrm{GP}, 15 \% \mathrm{MS})$ respectively and are compared to the conventional concrete.

\section{Experimental Methodology}

\subsection{Materials Required}

Portland Pozzolana Cement having specific gravity of 3.15 was used as binder adhering to IS-8112. River sand having specific gravity of 2.38 and crushed granite powder having specific gravity of 2.58 were used as fine aggregatesthat passed through $4.75 \mathrm{~mm}$ and retained on 150micron sieve. Natural aggregates having specific gravity and fineness modulus of 2.76 and 7.54 and marble stone having specific gravity and fineness modulus of 2.70 and 7.55 were used as course aggreagtes that passed through $20 \mathrm{~mm}$ and retained on $10 \mathrm{~mm}$ sieve. CDA with a specific gravity 
of 2.55 was used. Ordinary portable water from the college campus was used to prepare concrete.
The concrete mix was designed for M20 grade as per IS 10262:2009 with mix proportion having w/c ratio as 0.45 .

\subsection{Mix Design}

Table 1: Details of mix proportioning for conventional concrete $(\mathrm{C} 0)$

\begin{tabular}{|c|c|c|c|c|}
\hline Description & Cement & Water & Fine aggreagte & Course aggregate \\
\hline Quantity $\left(\mathbf{k g} / \mathbf{m}^{3}\right)$ & 380 & 160 & 650 & 1200 \\
\hline
\end{tabular}

\subsection{Methods}

The control mix of concrete was casted for the following ratios of replacement (as shown in Table 2), in which cement was replaced by cowdung ash, fine aggregate was replaced by granite powder and course aggreagte was replaced by marble stone.

Table 2: Replacement Ratios

\begin{tabular}{|c|c|}
\hline Specimen No. & Replacement ratios \\
\hline C0 & - \\
\hline C1 & $5 \%$ CDA, 10\% Granite powder and 15\% Marble stone \\
\hline C2 & $5 \%$ CDA, 15\% Granite powder and 30\% Marble stone \\
\hline C 3 & 10\%CDA, 15\% Granite powder and 30\% Marble stone \\
\hline C4 & $5 \%$ CDA, 7.5\% Granite powder and 15\% Marble stone \\
\hline
\end{tabular}

The compressive strength test was performed using $150 \mathrm{~mm}$ size cube at the age of 7,14 and 28 days of curing. The split tensile strength test was performed using $150 \mathrm{~mm}$ diameter $\mathrm{x} 300 \mathrm{~mm}$

\section{Test Results and Discussions}

\subsection{Compressive Strength Test}

Figure 1 represents the comparison of compressive strength for 7 , 14 and 28 days of curing for conventional cube and the cubes with replaced materials.

From the obtained compression test results, we infer that the increase in percentage of cowdung ash decreases the strength. Thus, 5\% is the Optimum Percentage of addition gives better results. Also, the optimum percentage of granite powder is $7.5 \%$ beyond which the strength seems to be decreasing. Similarly, optimum percentage of addition of marble stone is $15 \%$. Increasing marble stone beyond this limit doesn't give satisfactory results comparatively.

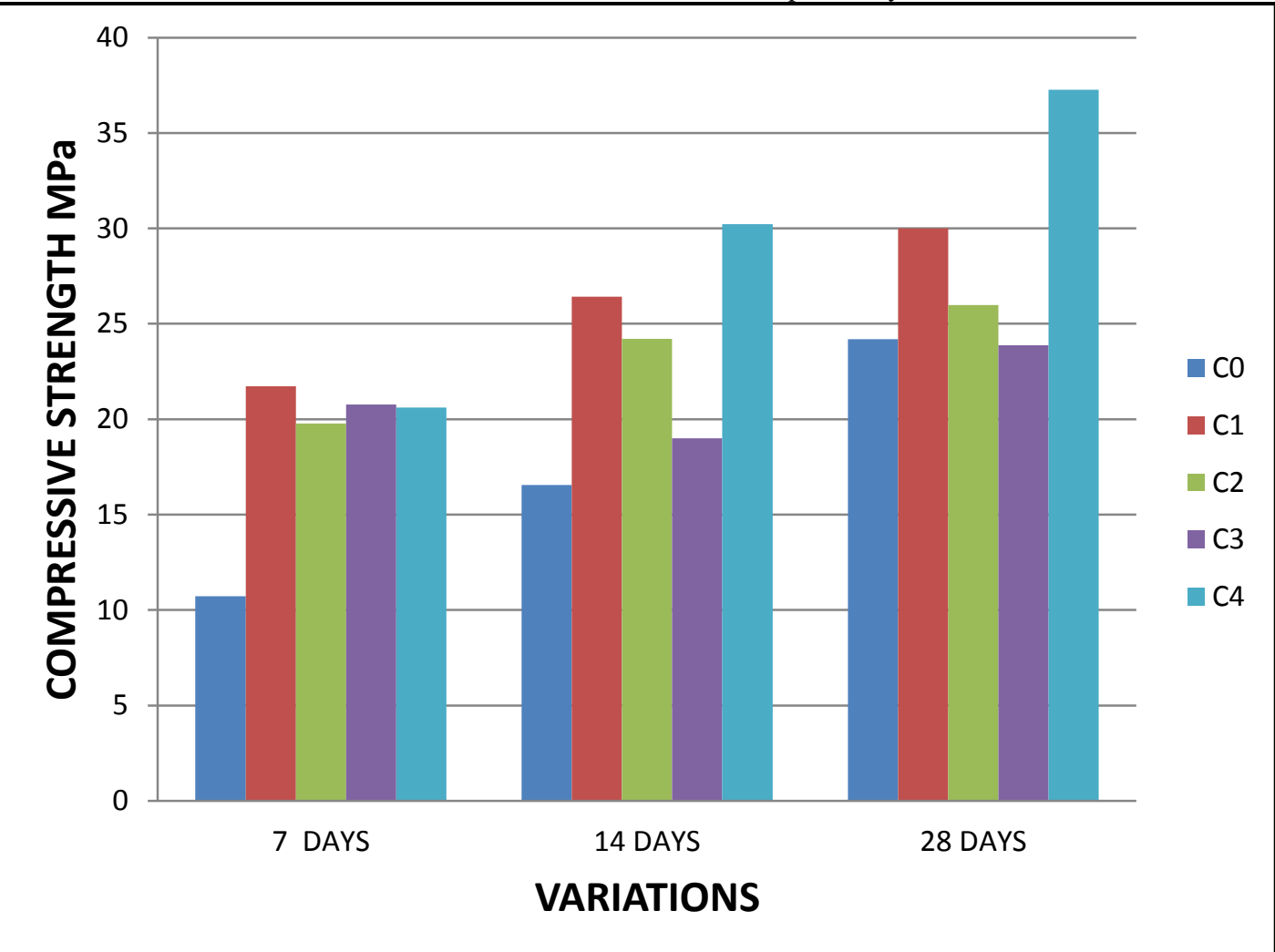

Fig. 1: Compressive Strength Results

\subsection{Split Tensile Strength Test}

Figure 2 represents the comparison of Split tensile strength for 14 and 28 days of curing for conventional cube and the cubes with replaced materials.
From the split tensile test results, it was found that increase in CDA improves tensile strength. The Split tensile strength was good at $10 \% \mathrm{CDA}, 15 \%$ granite powder, $30 \%$ marble stone.C $3(10 \%, 15 \%, 30 \%)$ cylinder has better tensile strength at early stages. The tensile strength of replaced concrete is better than conventional concrete. 


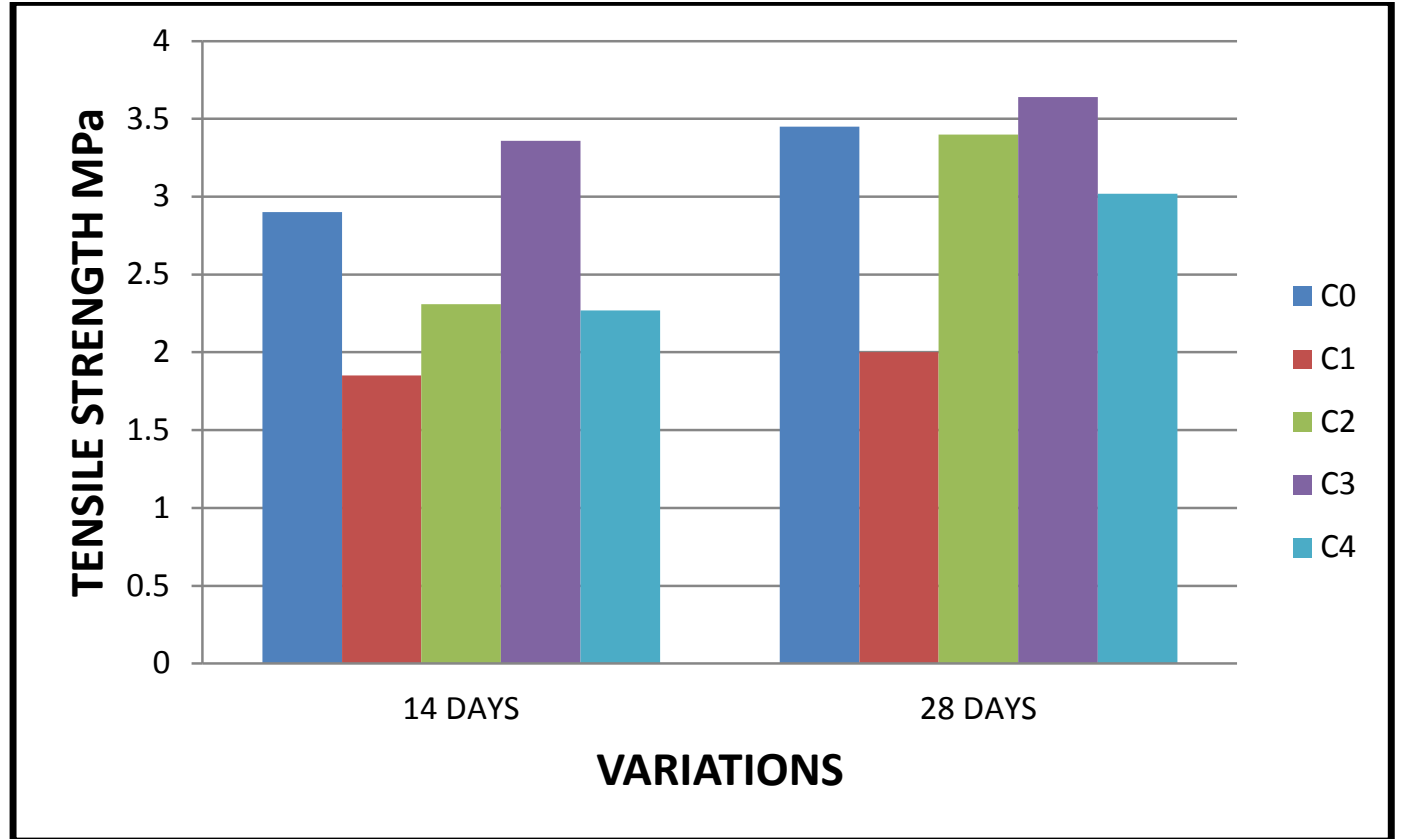

Fig. 2: Split tensile Strength Results

\section{Conclusions}

- From the experimental study, we conclude that the strength characteristics of replaced material give better results compared to conventional concrete.

- The C4 cube with $\operatorname{CDA}(5 \%)$, Granite Powder $(7.5 \%)$ and marble stone $(15 \%)$ has better compressive strength compared to other ratios and conventional concrete.

- Considering the split tensile strength, C3(10\%CDA, $15 \%$ Granite Powder, 30\% Marble stone) gives better result.

- $\quad$ Therefore, recommended mix is C4 (5\% CDA, 7.5\% Granite powder and $15 \%$ Marble stone), which has good compressive strength and tensile strength which lies within the permissible value of $1 / 8-1 / 12$ to compression strength.

- Use of these replacements in concrete reduces the environmental impact, effect of waste disposal and demand of cement in concrete.

\section{References}

[1] Prof. Roshanlal, Er. Kuldeep Kumar, An investigation on strength characteristics of concrete containing recycled aggregates of marble and granite waste, International journal of progresses in civil engineering(IJPCEL), 2014, volume-1(1).

[2] Ojedokun.O.Y, Adeniran.A.A, Raheem.S.B and Aderinto.S.J, Cow Dung Ash (CDA) as Partial Replacement of Cementing Material in the Production Of Concrete, British Journal of Applied Science \& Technology, 4(24): 3445- 3454, 2014

[3] Omoniyi.T, Duna.S, Mohammed.A, Compressive strength Characteristic of Cow dung ash blended cement Concrete, International Journal of Scientific \& Engineering Research, July2014, Volume 5(7).

[4] Chaithra H L, Pramod K, Dr. Chandrashekar A, An Experimental Study on Partial Replacement of Cement by Ggbs and Natural Sand by Quarry Sand in Concrete, International Journal of Engineering Research \& Technology (IJERT), May-2015 , Vol. 4(5), ISSN: 2278-0181

[5] Dr.T. Felix Kala, Effect of Granite Powder on Strength Properties of Concrete , International Journal Of Engineering And Science, May 2013, Vol.2(12), Pp 36-50

[6] Pranali K. Kohad*, Swapnil R. Satone, An Experimental Investigation Of Partial Replacement Of Aggregate By Various Percentage Of Recycled Aggregate \& Marble Sludge Powder-A Review , International Journal of Engineering Research \& Technology (IJERT), January-2013, Vol. 2(1).

[7] T. Felixkalaand P. Partheeban, Granite powder concrete, Indian Journal of Science and Technology, Mar 2010, Vol. 3(3).
[8] Manasseh JOEL, Use of Crushed Granite Fine as Replacement to River Sand in Concrete Production, December 2010. 25

[9] SudarshanD.Kore, A.K.Vyas, Impact of marble waste as coarse aggregate on properties of lean cement concrete, January 201610. Arivumangai, T. Felixkala, Strength and Durability Properties of Granite Powder Concrete , Journal of Civil Engineering Research 2014. 